\title{
Plasmid DNA Analysis of Pasteurella multocida Serotype B isolated from Haemorrhagic Septicaemia outbreaks in Malaysia
}

\author{
Jamal, H. *, Chua, K. H., Frederick, D., Mahmood Ameen, A. and Salmah, I. \\ Molecular Bacteriology Laboratory, Department of Molecular Medicine, \\ Faculty of Medicine, University of Malaya 50603 Kuala Lumpur, Malaysia. \\ Email: jamalum2004@yahoo.com
}

\begin{abstract}
A total of 150 purified isolates of Pasteurella multocida serotype B were used (Salmah, 2004) for plasmid DNA curing experiment to determine hyaluronidase activity, antibiotic resistance pattern (ARP) and mice lethality test $\left(L D_{50}\right)$ for their role of pathogenicity. A plasmid curing experiment was carried out by using the intercalating agent; ethidium bromide and rifampicin, where it was found all the plasmids had been 'cured' (plasmidless) from Pasteurella multocida. All of these plasmidless isolates maintained their phenotypic characteristics. They showed the same antibiotic resistance pattern as before curing, produced hyaluronidase and possessed lethality activity in mice when injected intraperitoneally (i.p). Based on this observation, the antibiotic resistance, hyaluronidase activity and mice virulence could probably be chromosomal-mediated. Plasmids were detected $100 \%$ in all $P$. multocida isolates with identical profile of 2 plasmids size 3.0 and $5.5 \mathrm{~kb}$. No large plasmids could be detected in all isolates. Since all the isolates appeared to have identical plasmid profiles, they were subjected to restriction enzyme (RE) analysis. From RE analysis results obtained, it can be concluded that the plasmid DNA in serotype B isolates are identical. Only 4 of 32 REs were found to cleave these plasmids with identical restriction fingerprints; BgllI, HaellI, Rsal and Sspl. From RE analysis results, it can be concluded that the plasmid DNA isolates are identical. This plasmid might not played any role in pathogenicity of Pasteurella multocida serotype $B$, however this information is important for the construction of shuttle vectors in genetic studies of the pathogenicity of haemorrhagic septicaemia (HS).
\end{abstract}

Keywords: Pasteurella multocida serotype B, plasmid, haemorrhagic septicaemia, hyaluronidase, pathogenicity.

\section{INTRODUCTION}

Haemorrhagic septicaemia (HS) is an acute septicaemic pasteurellosis, caused by Pasteurella multocida (serotype B), which principally affects cattle and water buffaloes. The disease continues to be the major cause of mortality of cattle and buffaloes in Malaysia. Losses in West Malaysia were estimated at about M\$1.5 million in 1966 (Thomas, 1972) with an average annual lose estimated at $M \$ 200,000$ for 1967-1976 (Joseph, 1979). The disease occurs in many parts of the world, predominantly in the tropics. Two cases of latest occurrence of HS in Malaysia have been both reported in Terengganu state: Kuala Terengganu (2000) and Rantau Panjang (2001) in which the disease was confirmed to be caused by Pasteurella multocida serotype B.

Plasmid has been used in several studies in order to learn more about the pathogenicity and virulence mechanism (Shivshankara, 2000) of the $P$. multocida. Plasmid profile analysis is a useful tool in epidemiological studies (Salmah, 1997, 2000 and 2004). Various studies have been done on $P$. multocida plasmid; in one such studies a cryptic plasmid of $P$. multocida related to its protein has been reported by McGee (2001), elsewhere Plasmid DNA has been used as a probe to identify the species by Zhao and Aoki (1992).

The aim of this study was to characterize the plasmid *Corresponding author
DNA in $P$. multocida obtained from HS outbreaks by restriction endonuclease digestion. The finding of this preliminary study would help to further investigate whether any of these plasmids are related to virulence mechanism (pathogenicity) of $P$. multocida.

\section{MATERIALS AND METHODS}

\section{Bacterial isolates and media}

All $P$. multocida isolates used in this study were collected from bovine (cattle, cows and buffaloes) from different outbreaks of HS at different time (year of 1988, 1989, 1990, 1991, 1999, 2000 and 2001) and locations (Malacca, N. Sembilan and Kelantan) in Malaysia. A total of hundred fifty (150) P. multocida isolates of pure cultures were collected from Veterinary Diagnostic Laboratory, Petaling Jaya. Isolates were subcultured once onto Brain Heart Infusion (BHI) blood agar, incubated at $37^{\circ} \mathrm{C}$ overnight before amplified in $\mathrm{BHI}$ broth.

Once a $P$. multocida isolate was identified, it was transferred to a fresh bijou bottle $\mathrm{BHI}$ agar slant, labelled and stored until used for its phenotypic characterization such as hyaluronidase detection, antibiotic sensitivity testing, mice lethality test $\left(\mathrm{LD}_{50}\right)$ and plasmid DNA analysis. 


\section{Hyaluronidase detection by rapid plate method}

A culture-drop and streaking plate methods were used in this study. The plate cultures were prepared as mentioned earlier (Salmah, 1997). These plates were flooded with $2 \mathrm{~N}$ acetic acid for 10 minutes. The non-degraded substrates precipitate as a conjugate with the albumin, leaving a clear zone around those colonies which produce soluble enzyme that attack the hyaluronate. Hyaluronidase activity is well known among coagulase positive staphylococci; therefore $S$. aureus was used as a positive control in this experiment.

\section{Antibiotic susceptibility testing by E-test}

All animal isolates of $P$. multocida were subcultured onto $\mathrm{BHI}$ agar plates and antibiotic susceptibility was done using E-test strips obtained from $A B$ Biodisk, Sweden. Briefly, $P$. multocida inoculum was prepared in $\mathrm{BHI}$ broth (Difco) and turbidity was adjusted to MacFarland 0.5 turbidity standard. The inoculum was seeded onto Mueller-Hinton blood agar with $7 \%$ defibrinated sheep blood. Inoculated plates were incubated at $37^{\circ} \mathrm{C}$ for 18 hours. The MIC values were read at the end point of intersection between the zone edge and the E-test strip. The cut off values to decide antibiotic susceptibility in Etest were according to the manufacturer prescription.

\section{Mice lethality test $\left(L^{50}\right)$}

Mice lethality test was carried out as described by Jamal (2004). The inoculum was prepared from a brain heart infusion broth culture of $P$. multocida, which had been incubated at $37^{\circ} \mathrm{C}$ for 18 hours. The broth culture was then centrifuged and the cells were resuspended in Phosphate buffered saline (PBS). Mice were injected with $0.5 \mathrm{ml}$ of $10^{7}$ viable organisms intraperitoneally. The virulence (lethality) observation was made for 18-72 hours.

\section{Plasmid curing}

The procedure described by Caro et al., (1984) with modification was followed, using both ethidium bromide and rifampicin as chemical curing agents. The test organism was grown in $\mathrm{BHI}$ broth supplemented with ethidium bromide and rifampicin (final concentration 25$100 \mu \mathrm{g} / \mathrm{ml}$, respectively). Both sets were incubated at $42^{\circ} \mathrm{C}$ for 18 hours. Culture tube with highest concentration of the dye and showing visible growth was selected and was ten-fold diluted in fresh $\mathrm{BHI}$ broth, $500 \mu \mathrm{l}$ of the dilutions were spread onto $\mathrm{BHI}$ agar plates with the help of a sterile spreader. After overnight incubation at $37^{\circ} \mathrm{C}$, colonies were screened for loss of plasmid DNA, antibiotic resistance pattern and mice lethality test $\left(L D_{50}\right)$. All the results obtained were compared before and after curing experiment.

\section{Plasmid DNA detection}

All the isolates were grown overnight at $37^{\circ} \mathrm{C}$ in $3 \mathrm{ml} \mathrm{BHI}$ broth. Plasmid DNA was extracted by using Promega Wizard(C) Miniprep Plasmid DNA Purification Kit, in which the procedure was done according to the manufacturer's instruction. The presence of plasmid DNA after curing was detected by agarose gel electrophoresis.

\section{Plasmid DNA profiling and restriction enzyme analysis}

Plasmid DNA profiling and agarose gel electrophoresis were carried out as described recently (Salmah, 2004) against 150 strains isolated from outbreaks cases of HS in animals. Thirty (30) restriction endonuclease enzymes were tested for their ability to cleave the plasmids that have extracted from all the 150 P. multocida HS-causing isolates. The restriction endonucleases Sspl, Haell, Rsal, Bgll, Bglll, Hpall, Kpnl, Hpal, EcoRl, Eagl, Clal, Bcll, BamHI, Aval, Avall, Apal, Accl, Mscl, Ndel, Notl, Pstl, Pvul, Pvull, Sacl, Sall, Scal, Smal, Sphl, Xbal and Xhol were used under conditions recommended by the supplier (New England Biolabs. Inc., U.S.A. and Bethesda Research Laboratories, U.S.A.). Restricted DNA (0.2 to $1.0 \mu \mathrm{g}$ ) was subjected to electrophoresis in $1.2 \%$ agarose gels.

\section{RESULTS AND DISCUSSION}

\section{Phenotypic Characterization}

\section{Bacterial Morphology}

Gram-stained preparations from all cultures varied from uniform arrangements of Gram-negative short coccobacillary-shaped rods occurring singly, in pairs and occasionally in short chains, to preparation of Gramnegative rods of varying lengths.

The $P$. multocida colonies were 0.5 to $1.0 \mathrm{~mm}$ in diameter and smooth with entire edge, increasing in size to 1.0 to $2.0 \mathrm{~mm}$ with continued incubation at $37^{\circ} \mathrm{C}$ on $\mathrm{BHI}$ blood agar. Colonies were grayish-yellow, smooth, glistening and transparent with a butyrous consistency (Figure 1).

\section{Hyaluronidase production}

Hyaluronidase production was only demonstrated in all of the isolates that had been recovered from cases of HS (Figure 2). Similar findings were also reported in earlier study by Carter and Chengappa (1980), in their survey of 74 cultures of $P$. multocida, representing serotype $\mathrm{A}, \mathrm{B}, \mathrm{D}$ and $E$ had shown that only each of isolates serotype $B$ of $P$. multocida from cases of HS produced hyaluronidase.

The fact that only the type B HS cultures produced hyaluronidase is particularly interesting in that these cultures are known to be highly virulent. However, before one can conclude that only the type B HS cultures produced hyaluronidase, abundance of type $\mathrm{B}$ cultures 
and also type B from wound cases should be examined closely. If it is ultimately confirmed that only the type B HS isolates produce hyaluronidase, this characteristic may be of value in their identification. Whether or not this enzyme has a role in the pathogenesis of HS seems worthy of investigation.

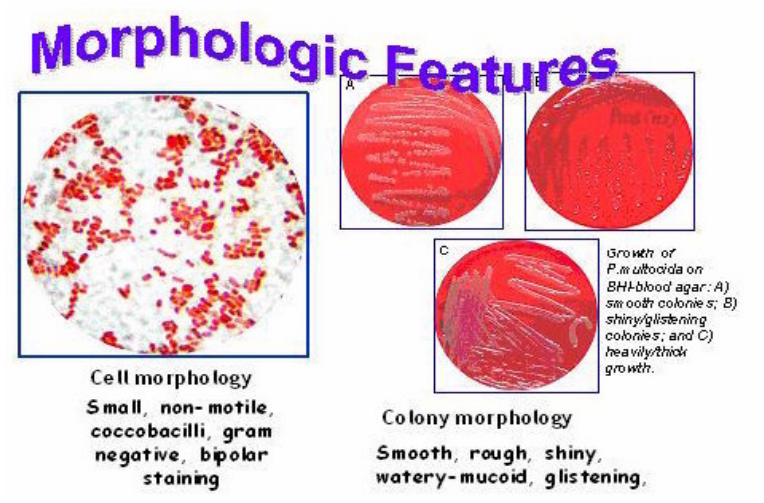

Figure 1: Cell and colony morphology of Pasteurella multocida isolated from HS outbreaks.

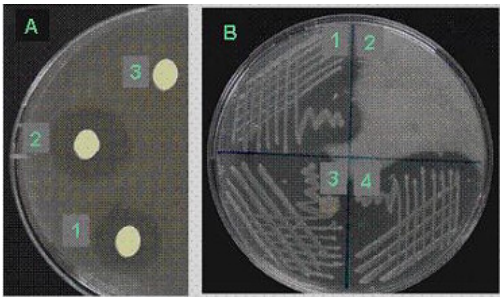

Figure 2: Rapid plate method of hyaluronidase test; (A) culture-spot method of S.aureus ATCC25933 (1) as a positive control; representative isolates of $P$. multocida serotype B (2) and E.coli ATCC 25922 (3) as a negative control; B) streaking method of S.aureus ATCC25933 (1) as a positive control; E. coli ATCC 25922 (2) as a negative control; and representative isolates of $P$. multocida serotype B $(3,4)$.

\section{Antibiotic resistance pattern (ARP)}

The antibiotic resistance phenotypes of the isolates in this study indicate that the $P$. multocida are almost always resistant to sulphonamides and spectinomycin irrespective of the serotype, time or location of isolation. All isolates were susceptible to chloramphenicol $(\mathrm{Cm})$, erythromycin $(\mathrm{Em})$, gentamicin $(\mathrm{Gm})$, kanamycin $(\mathrm{Km})$ and trimethoprim + trimethoxazole (Sxt). In this study, it was found that sulphonamides and spectinomycin were ineffective against $P$. multocida isolates. It therefore appears, that the $P$. multocida in Malaysia are generally more sensitive to the antibiotics tested compared to isolates studied elsewhere on the basis of the susceptibility results in this study. The antibiotics that can be considered for use against $P$. multocida are chloramphenicol, erythromycin and the aminoglycosides gentamycin and kanamycin.

\section{Mice lethality test $\left(L_{50}\right)$}

It was found that all isolates of $P$. multocida serotype B were virulent to mice and caused death within 18 hours. The histo-pathological examination showed the typical HS symptoms (Figure 3).

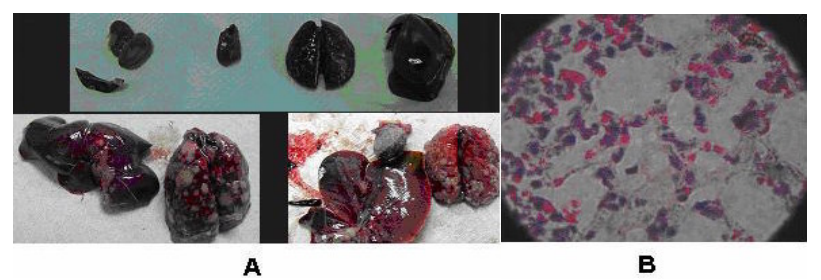

Figure 3: Histopathological analysis of $P$. multocida serotype A- Gross pathology and B-Histo-slide.

\section{Molecular Characterization}

\section{Detection of Plasmid DNA}

One hundred and fifty isolates of $P$. multocida were examined for the presence of plasmid DNA. All $P$. multocida isolates showed 2 plasmids bands of 3.0 and 5.5 $\mathrm{kb}$ in size (Figure 4). Plasmid profile analysis indicated that all isolates of $P$. multocida harboured plasmids with identical reproducible patterns on repetitive testing.

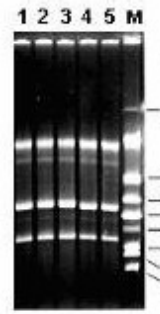

1988

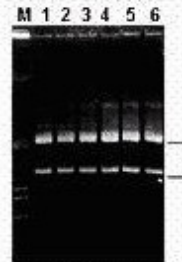

1991
M 1223456

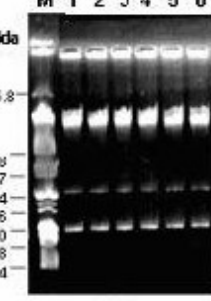

1989

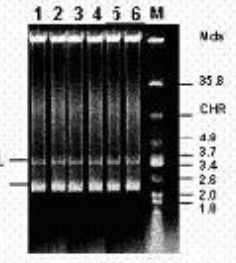

1999

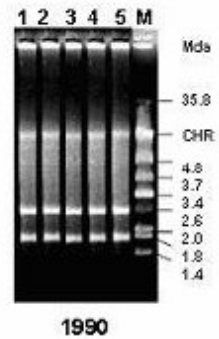

1990

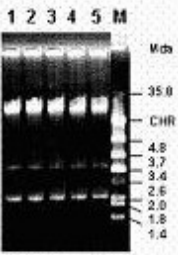

2000 and 2001
Figure 4: Agarose (1.0\%) gel electrophoresis of plasmid DNA extracted from representative of $P$. multocida isolated from HS outbreak in 1988 - 2001. E. coli V517 was used as molecular weight marker (Lane M). 


\section{Restriction Endonuclease (RE) Analysis}

Irrespective of the geographical distribution and the time of occurrence all the isolated $P$. multocida which cause HS disease in cattle and buffalos had common RE profile. All these plasmids contain a single unique site for Haell, which is four-base cutter enzyme. The recognition sequence for Haell is rich in bases guanine $(G)$ and cytosine C, while Bg/ll, Rsal and Sspl recognizes a DNA sequence that contains more adenines (A) and thymines (T) than Gs and Cs. These results indicate that $P$. multocida plasmid DNA contains more As and Ts than Gs and Cs. (Figure 5). Studies have indicated that the G-C content of $P$. multocida DNA was $40.3 \%$ (Berman and Hirsh, 1978) which means that the DNA is A-T rich. From $\mathrm{RE}$ analysis results, (Table 1) it can be concluded that the plasmid DNA isolates are identical. This strongly suggests that isolates of $P$. multocida from all HS outbreaks in Malaysia had only a single predominant plasmid profile and may have originated from a common ancestor.

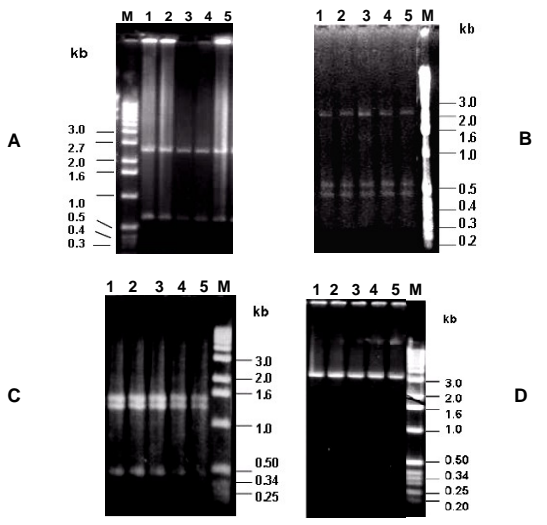

Figure 5: Agarose (1.2\%) gel electrophoresis of plasmids DNA of $P$. multocida HS isolates digested with Bg/ll (A), Rsal (B), Sspl (C) and Haelll (D).

Table 1: Restriction endonuclease digestion of $P$. multocida isolates from haemorrhagic septicaemia outbreaks.

\begin{tabular}{llll}
\hline $\begin{array}{l}\text { RE } \\
\text { Analysis }\end{array}$ & $\begin{array}{l}\text { No. of cutting } \\
\text { sites }\end{array}$ & $\begin{array}{l}\text { Size of fragments } \\
(\mathbf{k b})\end{array}$ & $\begin{array}{l}\text { Total } \\
(\mathbf{k b})\end{array}$ \\
\hline Bgll & 2 & $2.4,0.6$ & 3.00 \\
HaellI & 1 & 3.0 & 3.00 \\
Rsal & 3 & $2.0,0.55,0.45$ & 3.00 \\
Sspl & 3 & $1.30,1.20,0.5$ & 3.00 \\
\hline
\end{tabular}

\section{Plasmid Curing}

This study was carried out to detect the virulence determinant of $P$. multocida serotype $\mathrm{B}$ isolates causing $\mathrm{HS}$ whether is plasmid- or chromosomal-mediated. Therefore, $P$. multocida was subjected to plasmid curing via ethidium bromide and rifampicin. Once the curing experiment was successfully done, the isolate was subjected to plasmid screening, antibiotic resistance pattern and mice lethality test. Data (Table 2) shows the results obtained from the curing experiment. It was found all $P$. multocida isolates were able to cure plasmid by ethidium bromide and rifampicin with the least concentration of $50 \mu \mathrm{g} / \mathrm{ml}$. Both of the agents successfully cured the plasmid at concentration of $100 \mu \mathrm{g} / \mathrm{ml}$ (Figure 6).

Table 2: Effect of ethidium bromide and rifampicin in plasmid curing experiment of Pasteurella multocida serotype B isolates.

\begin{tabular}{|c|c|c|c|c|c|c|}
\hline \multirow[t]{2}{*}{$\begin{array}{l}\text { Representative } \\
\text { isolate }\end{array}$} & \multicolumn{3}{|c|}{$\begin{array}{l}\text { Ethidium } \\
\text { bromide }(\mu \mathrm{g} / \mathrm{ml})\end{array}$} & \multicolumn{2}{|c|}{$\begin{array}{l}\text { Rifampicin } \\
(\mu \mathrm{g} / \mathrm{ml})\end{array}$} & \multirow[b]{2}{*}{100} \\
\hline & 25 & 50 & 100 & 25 & 50 & \\
\hline Growth condition & +++ & ++ & + & +++ & ++ & + \\
\hline Colonies per plate & 300 & 50 & 8 & 280 & 38 & 10 \\
\hline $\begin{array}{l}\text { Colonies screened } \\
\text { for plasmid }\end{array}$ & 150 & 50 & 8 & 140 & 38 & 10 \\
\hline $\begin{array}{l}\text { Colonies } \\
\text { plasmidless }\end{array}$ & 0 & 26 & 8 & 0 & 15 & 10 \\
\hline
\end{tabular}

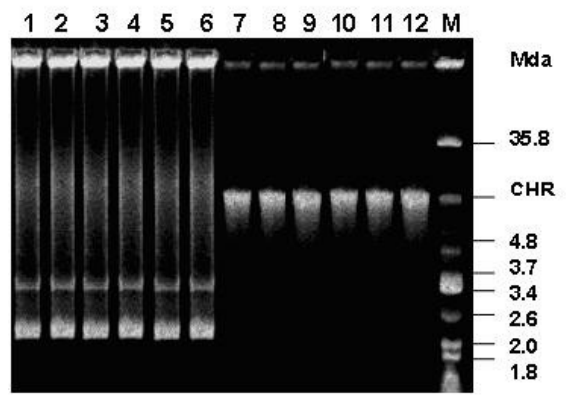

Figure 6: Agarose (0.7\%) gel electrophoresis showing plasmid DNA extracted from selected colonies of representative isolates of Pasteurella multocida serotype $B$ in curing experiment. Lane $1-6$ : before plasmid curing experiment; Lane 7 - 12: after plasmid curing experiment and Lane M: molecular weight standard marker, E. coli V517 used in this study.

\section{CONCLUSION}

In this study, it was observed that all the plasmid-cured isolates retained the same antibiotic resistance pattern, hyaluronidase activity and mice lethality test as before the curing experiment (Table 3 ). This shows that plasmid(s) in $P$. multocida might not carry any virulence gene, hyaluronidase activity and antibiotic resistance, which are most likely on the chromosome. From these findings we concluded that, plasmid does not play any role in the pathogenicity of Pasteurella multocida serotype B. Even though these cryptic plasmids do not code for any 'useful' product, they can be involved in the construction of shuttle vectors in genetic studies of the pathogenicity of HS. 
Table 3: Effect of curing experiment on phenotypic characteristics of $P$. multocida isolates.

\begin{tabular}{|c|c|c|}
\hline \multirow{2}{*}{$\begin{array}{l}\text { Phenotypic } \\
\text { characteristics }\end{array}$} & \multicolumn{2}{|c|}{ Curing Experiment } \\
\hline & Before & After \\
\hline $\begin{array}{l}\text { Antibiotic } \\
\text { Resistance } \\
\text { Pattern }\end{array}$ & $\begin{array}{l}\mathrm{S}_{3} \mathrm{SH}, \mathrm{S}_{3} \mathrm{SHTe}, \\
\mathrm{SmS}_{3} \mathrm{SHTe}, \\
\mathrm{AmS}_{3} \mathrm{SH}, \\
\mathrm{AmS}_{3} \mathrm{SHTe}, \\
\mathrm{SmS}_{3} \mathrm{SH}, \\
\mathrm{AmSmS} \mathrm{SH}, \\
\mathrm{AmSmS}_{3} \mathrm{SHTe}\end{array}$ & $\begin{array}{l}\mathrm{S}_{3} \mathrm{SH}, \mathrm{S}_{3} \mathrm{SHTe}, \\
\mathrm{SmS}_{3} \mathrm{SHTe}, \\
\mathrm{AmS}_{3} \mathrm{SH}, \\
\mathrm{AmS}_{3} \mathrm{SHTe}, \\
\mathrm{SmS}_{3} \mathrm{SH}, \\
\mathrm{AmSmS} \mathrm{SH}, \\
\mathrm{AmSmS}_{3} \mathrm{SHTe}\end{array}$ \\
\hline $\begin{array}{l}\text { Hyaluronidase } \\
\text { activity }\end{array}$ & All positive & All positive \\
\hline $\begin{array}{l}\text { Mice Lethality } \\
\text { Test }\left(L_{50}\right)\end{array}$ & All lethal & All lethal \\
\hline
\end{tabular}

\section{ACKNOWLEDGEMENTS}

I thank $\mathrm{Dr}$ Rahmat Omar, Department of Otorhinolaryngology (ENT), Faculty of Medicine, University of Malaya, Kuala Lumpur, for his technical expertise in photographic work.

\section{REFERENCES}

Berman, S.M. and Hirsh, D.C. (1978). Partial characterization of $\mathrm{R}$ plasmids from Pasteurella multocida from turkeys. Antimicrobial agents Chemotherapy. 14:348-352.

Caro, L., Churchward, G. and Chandler, M. (1984). Study of plasmid replication in vivo. In Methods in Microbiology. Vol. 17, eds. Bennet, P.M. and Grinsted, J: 97-122. Academic Press, New York.

Carter, G.R. and Chenggapa, M.M. (1980). Hyaluronidase production by type B Pasteurella multocida from cases of haemorrhagic septicaemia. Journal of Clinical Microbiolology II: 94-96.
Jamal, H. (2004). Pathogenicity Study of Recombinant Clone ABA392 Derived from HS Isolate of Pasteurella multocida Serotype B. In Forth Progress Meeting: Alternative Control of Haemorrhagic Septicaemia in Cattle. Cherating, Kuantan, Pahang. Malaysia.

Joseph, P.G. (1979). Hemorrhagic septicaemia in Peninsular Malaysia. Kajian Veterinar. 11:65-79.

McGee, J.E. and Bejcek, B.E. (2001). A Cryptic Plasmid from Pasteurella multocida has a predicted protein nearly identical to a transport protein from Actinobacillus actinomycetemcomitans. Plasmid, July, vol. 46, no.1, pp.60-64(5). Academic Press.

Salmah, I. (1997). Molecular studies of Pasteurella multocida animal isolates. M.Sc. thesis, University of Malaya, Malaysia.

Salmah, I. (2000). Molecular characterization of virulentdeterminant of recombinant clone ABA392 from Pasteurella multocida PMB202 of serotype B animal isolate. PhD Thesis, University Malaya.

Salmah, I. (2004). Plasmid DNA profiling of Pasteurella multocida serotype A, B, D and Untypable (U) isolates from animals. Journal of Animal and Veterinary Advances (JAVA). 3 (3): 130-135.

Shivashankara, N., Singh, V. P., Saxena, M.K. and Kumar, A.A. (2000). Plasmid profile analysis of Pasteurella multocida. Indian Journal of Comparative microbiology, Immunology and Infectious Diseases. Jul-Dec., 21(2):115-7.

Thomas, J. (1972). The control of hemorrhagic septicaemia in west Malaysia. Trop. Anim. HealthProd. 4:95-101.

Utusan Malaysia (13 januari; 14 januari, 2000). Usaha cegah Hawar berdarah; Awas daging lembu dijangkiti hawar berdarah.

Utusan Malaysia (12 julai, 2001). 'Rantau Panjang kini daerah hawar.'

Zhao, J. and Aoki, T. (1992). Plasmid Profile Analysis of Pasteurella piscicida and Use of a Plasmid DNA Probe to Identify the Species. Journal of Aquatic Animal Health 4(3):198-202. 